\title{
Persistent $\boldsymbol{H}$. pylori colonization in early acquisition age of mice related with higher gastric sialylated Lewis $x$, IL- I 0 , but lower interferon- $\gamma$ expressions
}

\author{
Yao-Jong Yang1,5, Hsiao-Bai Yang2,6, Jiunn-Jong $\mathrm{Wu}^{3}$ and Bor- \\ Shyang Sheu*4,5
}

\begin{abstract}
Address: ${ }^{1}$ Departments of Pediatrics, Medical College, National Cheng Kung University, Taiwan, Republic of China, ${ }^{2}$ Department of Pathology, Medical College, National Cheng Kung University, Taiwan, Republic of China, ${ }^{3}$ Department of Medical Laboratory Science and Biotechnology, Medical College, National Cheng Kung University, Taiwan, Republic of China, ${ }^{4}$ Department of Internal Medicine, Medical College, National Cheng Kung University, Taiwan, Republic of China, ${ }^{5}$ Institute of Clinical Medicine, Medical College, National Cheng Kung University, Taiwan, Republic of China and ' ${ }^{6}$ Department of Pathology, Ton-Yen General Hospital, Hsinchu County, Taiwan, Republic of China
\end{abstract}

Email: Yao-Jong Yang - yaojong@mail.ncku.edu.tw; Hsiao-Bai Yang - hbyang@tyh.com.tw; Jiunn-Jong Wu - jjwu@mail.ncku.edu.tw; BorShyang Sheu* - sheubs@mail.ncku.edu.tw

* Corresponding author

Published: 27 December 2008

Journal of Biomedical Science 2009, 16:34 doi:10.1186/1423-0127-16-34

This article is available from: http://www.jbiomedsci.com/content//6/I/34

(c) 2009 Yang et al; licensee BioMed Central Ltd.

This is an Open Access article distributed under the terms of the Creative Commons Attribution License (http://creativecommons.org/licenses/by/2.0), which permits unrestricted use, distribution, and reproduction in any medium, provided the original work is properly cited.
Received: 29 May 2008

Accepted: 12 December 2008

\begin{abstract}
Background: $H$. pylori infection is less prevalent in childhood. This study validated whether the rates of $H$. pylori colonization depend on different acquisition ages, and correlate with the different gastric Lewis antigens or cytokine expressions after $H$. pylori acquisition.

Methods: We applied a young (7-day-old) C57BL/6 mice group $(n=50)$ and adult (6-week-old) C57BL/6 mice group $(n=50)$. In each group, 30 mice were challenged with $H$. pylori and 20 mice served as naïve control. The success of $H$. pylori colonization was assessed on the $2^{\text {nd }}$ week and the $8^{\text {th }}$ week, respectively. The intensity of the Lewis $x$, sialylated Lewis $x($ sialyl-Le $)$, and cytokine expressions, including TNF- $\alpha$, IFN- $\gamma$, IL- 6 , IL-IO, and IL-I $\beta$, were immunochemically stained and graded.
\end{abstract}

Results: On the $2^{\text {nd }}$ week after $H$. pylori challenge, the colonization rates of $H$. pylori were similar between the young mice group and the adult mice group $(89 \%$ vs. $100 \%, P>0.05)$. However, on the $8^{\text {th }}$ week, the $H$. pylori colonization rate was significantly lower in the young mice group than in the adult mice group $(53 \%$ vs. $95 \%, P=0.003)$. On the $8^{\text {th }}$ week, the young mice with a persistence of $H$. pylori colonization had higher sialyl-Lex, higher IL-I0, and lower IFN- $\gamma$ than those of the mice that lost colonization during the $2^{\text {nd }}$ to the $8^{\text {th }}$ week $(P<0.05)$.

Conclusion: The persistence of $H$. pylori colonization could be an acquisition-age determinant process. After $H$. pylori exposure at an early acquisition age, the host response with a higher sialylLe $^{\mathrm{x}}$ and IL- 10 , but a lower IFN- $\gamma$ correlates to the consequent persistence of $H$. pylori colonization. 


\section{Introduction}

Helicobacter pylori infection can cause chronic gastritis and even peptic ulcer disease in both children and adults $[1,2]$. In epidemiological studies, the seropositivity of $H$. pylori has been shown to be less in children than in adults $[3,4]$. A follow-up cohort study showed that the highest incidence of seroconversion occurs in early childhood and gradually decreases with age [3]. Several studies have suggested that an early acquisition of $H$. pylori infection in childhood may possibly lead to a subsequent loss of colonization [3-6]. However, the exact regulations within children to determine either loss or persistence of $H$. pylori colonization after early acquisition remains not wellknown.

A blood group binding adhesin (BabA) of H. pylori selectively binds to the fucosylated Lewis antigen (Le $\left.{ }^{b}\right)$ of gastric cells mediating a heavy bacterial colonization [7-9]. The other sialic acid-binding adhesin (SabA) of H. pylori binds to the gastric sialylated Lewis $\mathrm{x}$ antigen (sialyl-Le ${ }^{\mathrm{x}}$ ) alternatively assisting the persistent colonization after chronic inflammation [10], and especially becomes important when the Le $\mathrm{e}^{\mathrm{b}}$ antigen of the host is absent or weak [11]. Our recent study disclosed that $H$. pyloriinfected children had a significant increase of sialyl-Lex, but not Le ${ }^{b}$ expression [12]. It is thus interesting to check whether the persistence of the early acquisition of $H$. pylori in childhood could be related with the variable host responses of gastric inflammation or of epithelial sialylation to adapt the SabA of H. pylori.

With adult C57BL/6 mice older than six weeks of age, the clinical $H$. pylori strains can successfully colonize most of the mice for more than six months $[13,14]$. The chronic $H$. pylori infection leads to diverse Th1 type predominant gastric inflammations with variable pro-inflammatory and Th1-dominant type cytokine responses among different hosts [15-18]. Accordingly, the current study aimed at first to check whether the persistence of $H$. pylori colonization could be an acquisition-age determinant process. In addition, this study attempted to answer whether the variable sialyl-Le ${ }^{\mathrm{x}}$ and the inflammatory cytokine expressions after $H$. pylori challenge could determine the persistent colonization of $H$. pylori infection, especially in mice receiving the challenge of early acquisition.

\section{Materials and methods \\ Mice groups and $\mathrm{H}$. pylori isolates for challenge experiment}

This study used 100 C57BL/6 mice (50 seven-day-old young mice and 50 six-week-old adult male mice), including 60 in the experimental group challenged with a type 1 , SabA-positive H. pylori clinical isolate (HP 625) and 40 in naïve controls. The multiplications of the $H$. pylori isolates were applied with the same method as our previous mice model study to achieve a density of $0.8 \times 10^{8} \mathrm{CFU} / \mathrm{ml}$. [19]. For the experimental group, a bacteria suspension $0.1 \mathrm{ml}$ for young mice and $0.5 \mathrm{ml}$ for the adult mice was orally inoculated for three consecutive days, respectively. Ten each of the young and adult mice of the control group were sacrificed at the $2^{\text {nd }}$ and the $8^{\text {th }}$ week. In the experimental mice, ten each of the young and adult mice at the $2^{\text {nd }}$ week and 20 each of the young and adult mice at the $8^{\text {th }}$ week after inoculation were sacrificed by intra-peritoneal injection of pentobarbital (150-200 mg/kg). The isolated stomachs were incised along the greater and lesser curvatures into two halves. One half was formalin-embedded for histology and Lewis antigen examinations. The other half was immediately placed in buffer, frozen on dry ice, and stored at $-80^{\circ} \mathrm{C}$ for cytokine examination. $H$. pylori infection was proven by a rapid urea test and histological examination.

\section{Gastric histology of mice}

Two investigators including one pathologist, unaware of the demographic data and colonization results, analyzed the gastric histology. Applying the method of our previous mice model [19], the histological parameters, including $H$. pylori density (range 0-4), acute inflammatory score (AIS, range 0-3), chronic inflammation score (CIS, range $0-3$ ), atrophic change (AT, range 0-1), and intestinal metaplasia (IM, range $0-3$ ) were evaluated topographically over the antrum, corpus and cardia, respectively. The grading system of $H$. pylori density used was as follows: 0 , no bacteria detected; 1 , a mild level of colonization and bacteria not detected in every gastric crypt; 2 , a mild level of colonization with bacteria detected in the majority of crypts present; 3, moderate to heavy colonization in all crypts; and 4, severe colonization with all crypts densely packed with bacteria. The results presented are the mean value of colonization for each group. The total H. pylori density (THPD) was defined as the sum of the densities obtained from the antrum, corpus and cardia, and thus ranged from 0 to 12 . The total acute (TAIS) and chronic (TCIS) inflammatory scores were also a sum of the score from three locations (range 0-9).

Bacterial infection of $H$. pylori was defined as the presence of any bacteria in the gastric sections, while mice were considered to have failed to be inoculated when no bacteria were seen in histology and negative for the CLO test.

\section{Immunohistochemical staining and scoring for gastric Lewis expression}

Immunostaining of gastric specimens for Lewis antigens was performed using the avidin-biotin-peroxidase technique with a VECTOR Ms.O.M. Immunodetection Kit. The primary monoclonal antibody (anti-Le ${ }^{\mathrm{x}}$, Signet Laboratories, Inc., Dedham, MA) was selected to detect the gastric Le $e^{\mathrm{x}}$ antigens $[11,12]$. Besides Le $e^{\mathrm{x}}$ antigen staining, the 
monoclonal antibody against sialyl-Le ${ }^{\mathrm{x}}$ (mouse IgM MAB2096, Chemicon International, Inc., Temecula, CA) was used [12]. Nonspecific binding sites were saturated with $2-2.5 \%$ bovine serum albumin. For each gastric site, the intensity of Le $e^{\mathrm{x}}$ (range 0-5) and sialyl-Le $\mathrm{e}^{\mathrm{x}}$ (range 0-4) was scored according to the topography of the staining (Figure 1). Total gastric Lewis antigen intensity for Le ${ }^{\mathrm{x}}$ and sialyl-Le ${ }^{\mathrm{x}}$ was the sum of the antrum, corpus and cardia (range 0-15 in Le ${ }^{\mathrm{x}}$ and 0-12 in sialyl-Le ${ }^{\mathrm{x}}$ ).

\section{Immunohistochemical staining and scoring for cytokines expression}

The frozen sections $(4 \mu \mathrm{m})$ were dried at room temperature for $2 \mathrm{~h}$, and fixed with 3.7\% formaldehyde for $1 \mathrm{~min}$. After washing with PBS twice, the samples were fixed with cold acetone and then washed with PBS. The Mouse Ig Blocking Reagent (VECTOR Laboratories, Burlingame, CA, U.S.A.) was used for blocking nonspecific binding sites. The rat anti-mouse monoclonal antibodies (TNF- $\alpha$, IL-6, IL-10, IL-1 $\beta$, and IFN- $\gamma$ ) and the rabbit anti-mouse polyclonal antibody (IL-1 $\beta$ ) were used as the primary antibody. The HRP polymer conjugate broad spectrum (Zymed Laboratories Inc. South San Francisco, CA, U.S.A.) was used as the $2^{\text {nd }}$ antibody. The AEC kit was used to illustrate the stain. The intensity of each cytokine was scored according to the distribution of positive staining cells on the epithelium (range 0-3), and on the lamina propria components, including the matrix, polymorphonuclear cells, lymphocytes, and fibrocytes (Table 1).

\section{Statistical analysis}

The Pearson's $\chi^{2}$ test was used to test the difference of colonization rates between the experimental and control mice. The histological parameters, Lewis antigens, and the cytokine expressions were compared with the Fisher's exact test for different subgroups. The Friedman test was used to test the difference of $H$. pylori density between the antrum, corpus and cardia of the stomach in each mouse. All tests were assessed two-tailed and a $p$ value $<0.05$ was taken as significant.
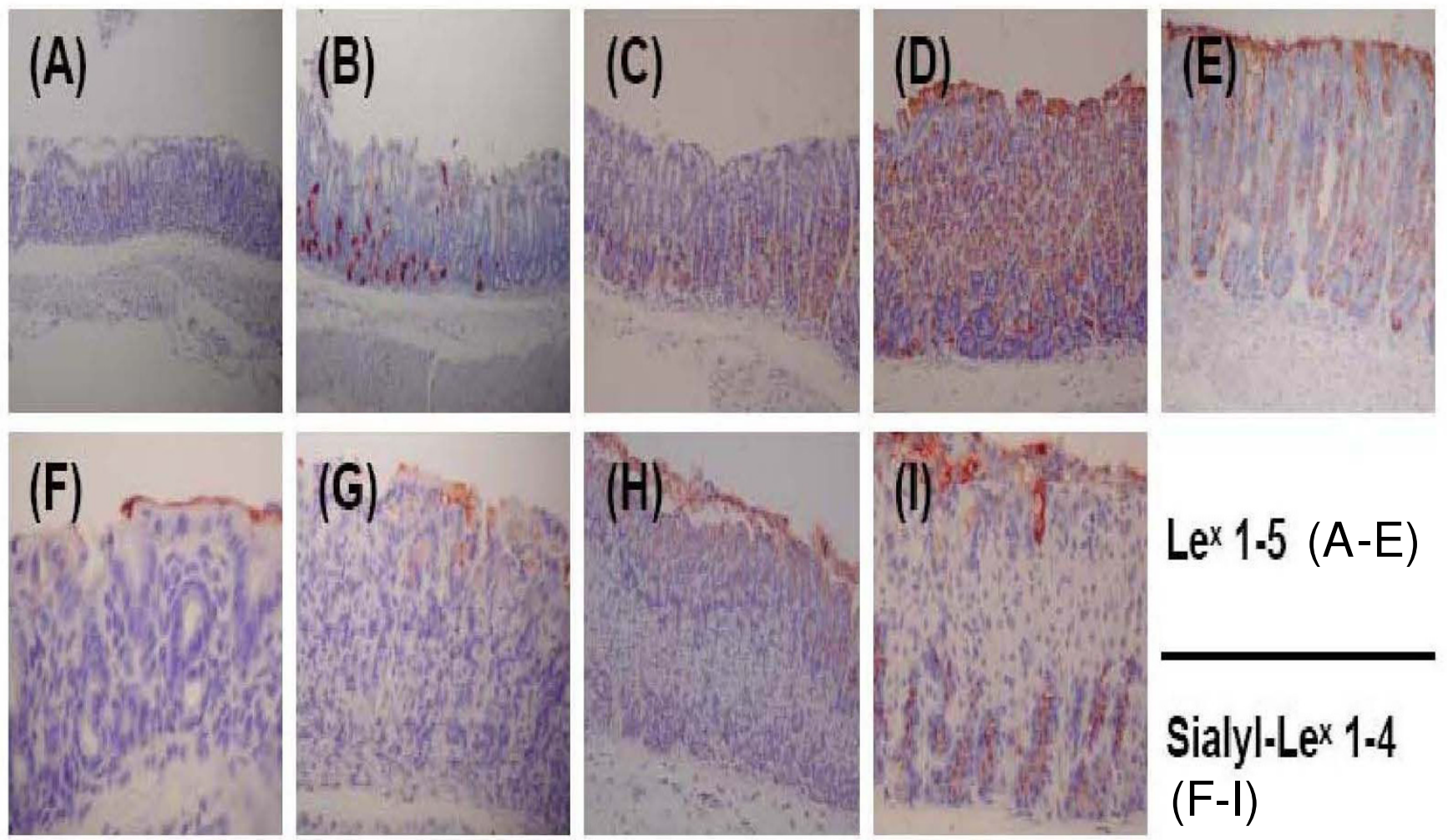
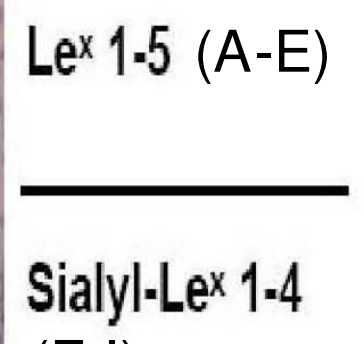
(F-I)

\section{Figure I}

The immunohistochemical (IHC) staining and grading of Lewis $x\left(\right.$ Le $\left.^{x}\right)$, and sialyl-Lewis $x$ (sialyl- Lex) antigens are shown for the gastric biopsies of mice (200x). The IHC staining showed negative for two Lewis antigens and was referred to as score 0 . For Lex, score I (A): scant staining (< 5\% in parietal cells of the deep glands; score 2 (B): deep glands $5-$ $50 \%$ staining and weak; score $3(C)$ : deep glands $>50 \%$ staining and strong; score $4(D)$ : whole layer of deep glands with superficial epithelium staining, no mucus expression; score $5(E)$ : whole layer with mucus expression. For sialyl- Lex, score I (F): only surface mucus positive; score $2(\mathrm{G})$ : Mucus and upper epithelium; score $3(\mathrm{H})$ : upper epithelium and deep glands (chief cells < $50 \%$ ); score 4 (I): upper epithelium and deep glands (chief cells $\geq 50 \%$ ). 
Table I: Scoring of cytokine expressions on the gastric epithelium and lamina propria.

\begin{tabular}{lcccc}
\hline & & & Score & \\
\cline { 2 - 4 } & 0 & 1 & 2 & 3 \\
\hline $\begin{array}{l}\text { Epithelium } \\
\text { Lamina propria }\end{array} \quad$ Negative & Less than 33\% & $33 \%-67 \%$ & More than 67\% \\
Matrix & Absence & Presence & \\
Fibrocyte & Absence & Presence & & \\
Neutrophil & Absence & Presence & & \\
\hline
\end{tabular}

The quantitative scoring of each cytokine on the epithelium was as follows: score I: positive staining in the cytoplasma of epithelial cells only on the upper 1/3 part of the epithelium; score 2: on the upper and middle part of the epithelium (1/3-2/3); score 3: on the whole layer of the epithelium (> 2/3). The positive staining of each cytokine on the lamina propria (lymphocytes, fibrocytes, and neutrophils) means there were more than five positive cells in a high power field of view in the microscopic examination.

\section{Results}

The rates of successful $\mathrm{H}$. pylori colonization in mice with different acquisition ages

On the $2^{\text {nd }}$ week after $H$. pylori challenge, $H$. pylori colonization was successful in $89 \%(8 / 9)$ of the young mice group and $100 \%(10 / 10)$ of the adult mice group. In contrast, on the $8^{\text {th }}$ week after $H$. pylori challenge, the colonization rate was significantly lower in the young mice than that in the adult mice (53\% vs. $95 \%, P=0.003$ ). For those mice with successful colonization either on the $2^{\text {nd }}$ or the $8^{\text {th }}$ week, the densities of $H$. pylori were evenly distributed on the antrum, corpus, and cardia in both young and adult mice $(P>0.05)$.

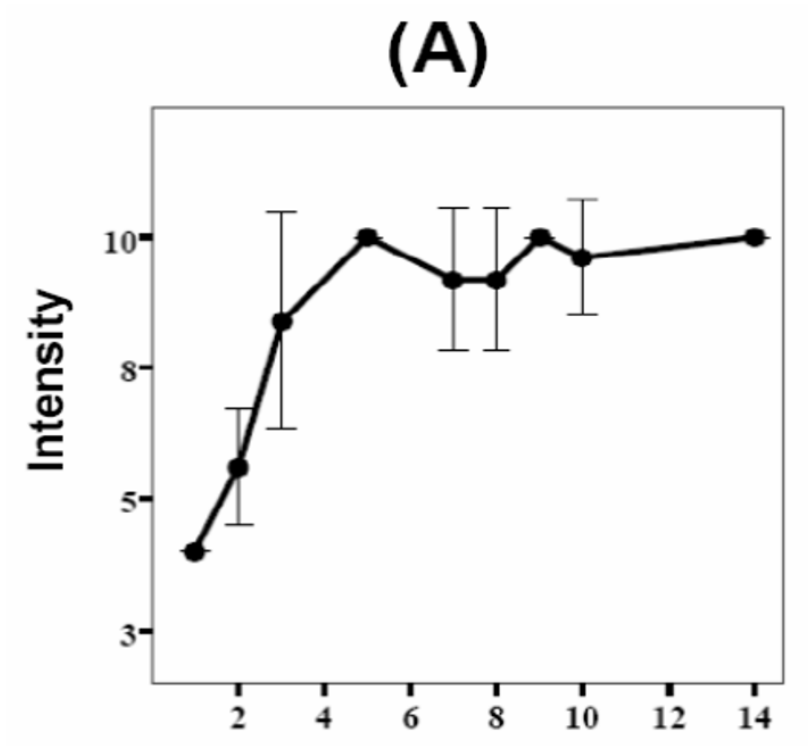

\section{Age-specific gastric Lewis antigen and cytokines expressions in the naïve mice}

In the naïve mice of both young and adult groups, the expressions of $\mathrm{Le}^{\mathrm{x}}$ and sialyl-Le ${ }^{\mathrm{x}}$ were weak on the gastric antrum. However, a gradual increase of the total intensity of Le $\mathrm{e}^{\mathrm{x}}$ and sialyl-Le ${ }^{\mathrm{x}}$ expressions was disclosed in the age increments (Figure 2A \&2B). Such an increase reached a plateau from the chronological age of near 5 weeks old. At the $2^{\text {nd }}$ week and the $8^{\text {th }}$ week after $H$. pylori challenge, the Lex expressions were not different between the colonized and the control mice in both young and adult groups.

The intensity of gastric cytokine expression varied between the different ages of mice and location. For the

\section{Figure 2}

The intensity of gastric Lewis antigens in naïve mice at different ages of life (A) Lewis $x$, (B) sialyl-Lewis $x$.

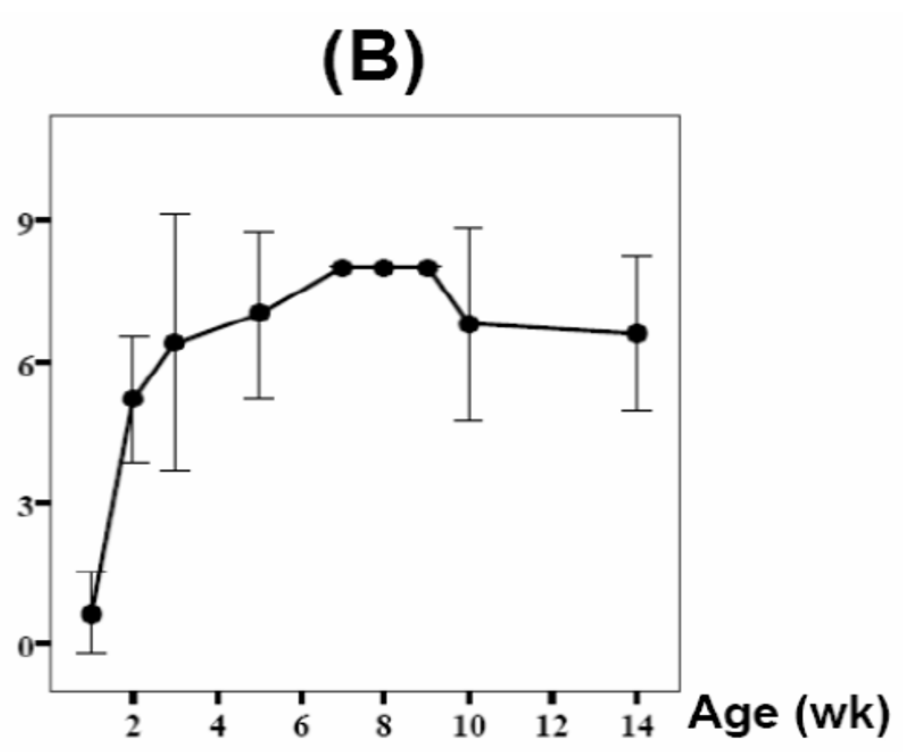


proinflammatory cytokines, there were no positive stainings of TNF- $\alpha$ and IL- 6 on superficial epithelium in any of the naïve mice. The positive stainings of TNF- $\alpha$ and IL- 6 on the lymphocytes, fibrocytes, and neutrophils over the lamina propria were significantly higher in mice aged $\geq 5$ weeks than those aged $<5$ weeks $(P<0.01$; Figure $3 \mathrm{~A}$ $\& 3 \mathrm{~B})$. The positive staining of IL- $1 \beta$ was mainly found on the epithelium and expressed early in mice aged $<5$ weeks. The rate of positive staining of IL- $1 \beta$ on neutrophils was higher in mice aged $\geq 5$ weeks than those aged $<5$ weeks $(P<0.05$; Figure $3 C)$.

In the early life of the mice, the positive IFN- $\gamma$ staining was in the majority found on the epithelium and matrix, as the intensity of positive IFN- $\gamma$ staining decreased after age $\geq 5$ weeks $(P<0.01$, Figure 3D). However, a significantly
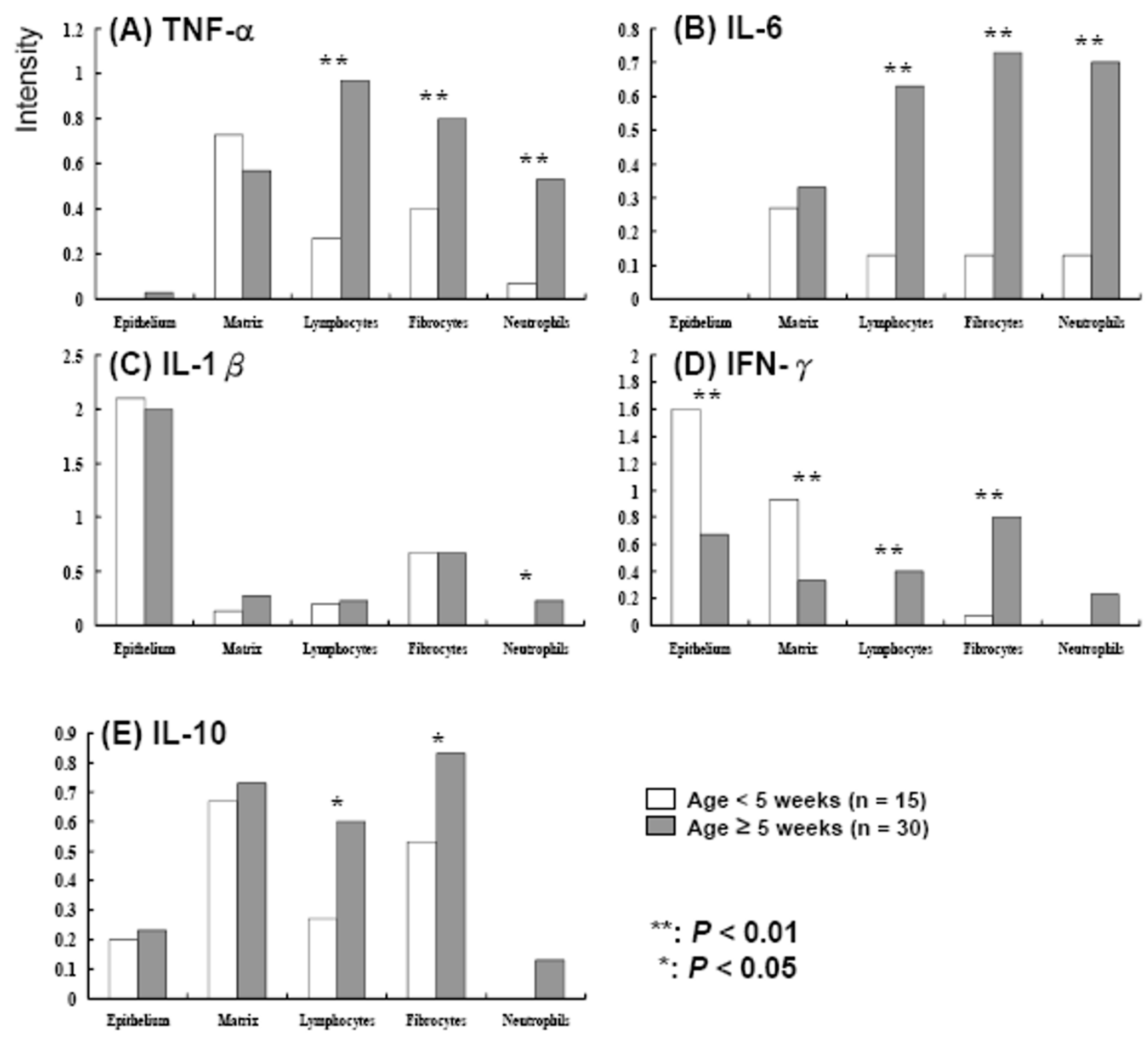

Age $<5$ weeks $(n=15)$

Age $\geq 5$ weeks $(n=30)$

$* *: P<0.01$
$*: P<0.05$

Figure 3

Gastric cytokine expressions on the epithelium and lamina propria between naïve mice aged $\geq 5$ weeks and $<5$ weeks. (A) Tumor necrotic factor alpha (TNF- $\alpha$ ), (B) interleukin 6 (IL-6), (C) interleukin I beta (IL-I $\beta$ ), (D) interferon gamma $(\mathrm{IFN}-\gamma)$, and $(\mathrm{E})$ interleukin $\mathrm{I0}(\mathrm{IL}-\mathrm{IO})$. 
higher rate of positive IFN- $\gamma$ staining on lymphocytes and fibrocytes was disclosed in the mice aged $\geq 5$ weeks than those aged $<5$ weeks $(P<0.01)$.

In contrast to the heavy IFN- $\gamma$ staining on the epithelium in the early life of mice, IL-10 was usually negative on the epithelium. The positive staining of IL-10 was higher on lymphocytes and fibrocytes in the mice aged $\geq 5$ weeks than in those aged $<5$ weeks $(P<0.05$; Figure 3E).

\section{Mice histology and Lewis antigen expression after $\mathrm{H}$. pylori infection}

On the $2^{\text {nd }}$ week after $H$. pylori challenge, the $H$. pylori-colonized young mice seemed to have a marginally higher rate of high TCIS (score $\geq 4$ ) than the control mice $(88 \%$ vs. $50 \%, P=0.15)$, but such a marginal significance was not disclosed in the adult mice (30\% vs. $30 \%, P=1.00)$. Moreover, in the young mice group, the mice with persistent colonization on the $8^{\text {th }}$ week had an evidently higher rate of high TCIS than the mice that lost colonization $(40 \%$ vs. $11 \%, P=0.30)$. On the $2^{\text {nd }}$ week after $H$. pylori challenge, the percentage of colonized young mice having a high intensity of sialyl-Le ${ }^{x}$ expression (score $\geq 7$ ) had dropped compared to that in the control mice (25\% vs. $60 \%, P=0.19)$. However, such a drop was not evident on the $8^{\text {th }}$ week ( $100 \%$ vs. $\left.90 \%, P>0.05\right)$ and with adult mice on the $2^{\text {nd }}$ week ( $90 \%$ vs. $\left.100 \%, P>0.05\right)$ and the $8^{\text {th }}$ week (58\% vs. $60 \%, P>0.05$ ) after $H$. pylori challenges.

\section{Gastric cytokines expression after $\mathbf{H}$. pylori infection}

On the $2^{\text {nd }}$ week after $H$. pylori challenge, the young mice with successful colonization had a significantly higher intensity of IL- 6 on fibrocytes (75\% vs. $0 \%, P=0.002)$ and matrix (75\% vs. $20 \%, P=0.05)$, but lower IFN- $\gamma(0 \%$ vs. $100 \%, P<0.001)$ on the matrix than the naïve controls (Table 2). Also in the adult mice, the mice with successful colonization were disclosed to have a lower rate of IFN- $\gamma$ expression on fibrocytes than the control mice (30\% vs. $90 \%, P=0.02$ ).

On the $8^{\text {th }}$ week after $H$. pylori challenge, the rates of high TNF- $\alpha(100 \%$ vs. $20 \%, P=0.02)$ on the matrix and high

Table 2: The gastric cytokine expressions on the $2^{\text {nd }}$ week of young and adult mice with persistent $H$. pylori colonization and naïve control mice.

\begin{tabular}{|c|c|c|c|c|c|c|c|}
\hline & \multirow[b]{2}{*}{ Parameter (\%) } & \multicolumn{3}{|c|}{ Young mice } & \multicolumn{3}{|c|}{ Adult mice } \\
\hline & & $\begin{array}{l}\text { Colonized } \\
\quad(n=8)\end{array}$ & $\begin{array}{l}\text { Control } \\
(n=10)\end{array}$ & $P$ value & $\begin{array}{l}\text { Colonized } \\
(n=10)\end{array}$ & $\begin{array}{l}\text { Control } \\
(n=10)\end{array}$ & $P$ Value \\
\hline \multirow[t]{4}{*}{ IL-6* } & Matrix & 75 & 20 & 0.05 & 70 & 30 & NS \\
\hline & Lymphocyte & 50 & 10 & NS & 60 & 70 & NS \\
\hline & Fibrocyte & 75 & 0 & 0.002 & 80 & 50 & NS \\
\hline & Neutrophil & 37.5 & 20 & NS & 20 & 70 & 0.07 \\
\hline \multirow[t]{4}{*}{ TNF- $\alpha *$} & Matrix & 87.5 & 70 & NS & 80 & 90 & NS \\
\hline & Lymphocyte & 62.5 & 40 & NS & 90 & 90 & NS \\
\hline & Fibrocyte & 87.5 & 40 & 0.07 & 100 & 90 & NS \\
\hline & Neutrophil & 12.5 & 10 & NS & 30 & 40 & NS \\
\hline \multirow[t]{4}{*}{ IL-I $\beta$} & Epithelium $\geq 2$ & 100 & 70 & NS & 100 & 90 & NS \\
\hline & Matrix & $\mathrm{a} 25$ & 0 & NS & 100 & 80 & NS \\
\hline & Lymphocyte & 25 & 20 & NS & 30 & 0 & NS \\
\hline & Fibrocyte & a25 & 60 & NS & 100 & 100 & NS \\
\hline \multirow[t]{5}{*}{ IFN- $\gamma$} & Epithelium $\geq 2$ & 0 & 30 & NS & 10 & 0 & NS \\
\hline & Matrix & 0 & 100 & $<0.001$ & 40 & 20 & NS \\
\hline & Lymphocyte & 0 & 0 & NS & 10 & 30 & NS \\
\hline & Fibrocyte & 12.5 & 10 & NS & 30 & 90 & 0.02 \\
\hline & Neutrophil & 0 & 0 & NS & 10 & 20 & NS \\
\hline \multirow[t]{4}{*}{ IL-10* } & Matrix & a 25 & 60 & NS & 100 & 80 & NS \\
\hline & Lymphocyte & 25 & 20 & NS & 60 & 60 & NS \\
\hline & Fibrocyte & a37.5 & 50 & NS & 100 & 80 & NS \\
\hline & Neutrophil & 12.5 & 0 & NS & 10 & 20 & NS \\
\hline
\end{tabular}

CIS: chronic inflammatory score; AIS: acute inflammatory score. *: colonized means mice infected with $H$. pylori with successful colonization (positive urea test and histology) on sacrifice. a: $P$ value $<0.01$; : $P$ value $\leq 0.05$ between the young and adult colonized mice. NS: no significance. *indicated on this parameter, the epithelium is rather weak for such cytokine on immunohistochemistry staining. 
IL-1 $\beta(100 \%$ vs. $20 \%, P=0.02)$ on fibrocytes were higher in the young mice with persistent colonization than in the control mice (Table 3). For the adult mice with successful colonization, the rates of high IFN- $\gamma(30 \%$ vs. $100 \%, P=$ $0.003)$, IL-10 (20\% vs. $100 \%, P=0.001)$ and IL-6 (50\% vs. $100 \%, P=0.03)$ on fibrocytes were also significantly lower than those of the control naïve mice. Nevertheless, it was more common in the colonized adult mice than the control mice to have a higher IFN- $\gamma$ ( $80 \%$ vs. $40 \%)$, IL-10 ( $80 \%$ vs. $40 \%$ ), and IL-6 ( $80 \%$ vs. $30 \%)$ on the matrix.

Higher sialyl-Lex coexists with higher IL-I 0, but lower INF$\gamma$ for H. pylori colonization

On the $2^{\text {nd }}$ week, the colonized young mice had no significant difference in the intensity of sialyl-Le expression than the control mice $(P>0.05)$. However, on the $8^{\text {th }}$ week after $H$. pylori challenge, the young mice with persistent colonization had a higher rate of evident sialyl-Le ${ }^{\mathrm{x}}$ expression (score $\geq 7$ ) than those of the mice that lost colonization ( $100 \%$ vs. $56 \%, P=0.03)$. In addition to showing a higher rate of sialyl-Le ${ }^{\mathrm{x}}$ expression (score $\geq 7$ ), all of the persistently $H$. pylori-colonized young mice significantly coexisted with lower IFN- $\gamma$ and higher IL-10 expressions than those mice that had lost persistent colonization on the $8^{\text {th }}$ week (Table $4,100 \%$ vs. $0 \%, P=0.008$ ).

Table 5 shows the scoring of IFN- $\gamma$ on the epithelium and IL-10 on the matrix and lymphocytes between mice with persistent and lost colonization at the $8^{\text {th }}$ week after $H$. pylori challenge. None of the young mice with persistent bacterial colonization had IFN- $\gamma$ expression on the epithelium but had obvious IL-10 expression on the matrix and lymphocytes as compared to the mice without colonization.

\section{Discussion}

Acquisition of $H$. pylori mainly occurs in childhood and spontaneous elimination of infection usually occurs in young children $[3-6,20]$. In this study, the C57BL/ 6 adult mice had a favorable $H$. pylori colonization rate of isolates ranging to more than $80 \%$, which is compatible with previous reports $[13,14]$. This high colonization rate in adult

Table 3: The cytokine expressions on the $8^{\text {th }}$ week of young and adult mice with persistent and lost $H$. pylori colonization and naïve control mice.

\begin{tabular}{|c|c|c|c|c|c|c|c|c|}
\hline \multirow{2}{*}{\multicolumn{2}{|c|}{ Variables (\%) }} & \multicolumn{4}{|c|}{ Young mice } & \multicolumn{3}{|c|}{ Adult mice } \\
\hline & & $\begin{array}{l}\text { Persistent colonization } \\
\qquad(\mathrm{n}=5)\end{array}$ & $\begin{array}{l}\text { Lost colonization } \\
\qquad(n=4)\end{array}$ & $\begin{array}{l}\text { Control } \\
(\mathrm{n}=10)\end{array}$ & $P+$ value & $\begin{array}{l}\text { Persistent colonization } \\
\qquad(\mathrm{n}=10)\end{array}$ & $\begin{array}{l}\text { Control } \\
(\mathrm{n}=10)\end{array}$ & $P$ value \\
\hline \multirow[t]{4}{*}{ IL-6* } & Matrix & 100 & 80 & 50 & NS & 80 & 30 & NS \\
\hline & Lymphocyte & 25 & 60 & 50 & NS & 70 & 70 & NS \\
\hline & Fibrocyte & 100 & 80 & 70 & NS & 50 & 100 & 0.03 \\
\hline & Neutrophil & 0 & 20 & 50 & NS & 20 & 70 & NS \\
\hline \multirow[t]{4}{*}{ TNF- $\alpha *$} & Matrix & 100 & 100 & 20 & NS & 100 & 60 & NS \\
\hline & Lymphocyte & 100 & 80 & 60 & NS & 90 & 90 & NS \\
\hline & Fibrocyte & 100 & 100 & 70 & NS & 100 & 80 & NS \\
\hline & Neutrophil & 25 & 20 & 60 & NS & 10 & 40 & NS \\
\hline \multirow[t]{5}{*}{ IL-I $\beta$} & Epithelium $\geq 2$ & 100 & 80 & 70 & NS & 100 & 80 & NS \\
\hline & Matrix & 75 & 40 & 30 & NS & 100 & 80 & NS \\
\hline & Lymphocyte & 50 & 60 & 0 & NS & 50 & 60 & NS \\
\hline & Fibrocyte & 100 & 60 & 20 & NS & 100 & 100 & NS \\
\hline & Neutrophil & 0 & 0 & 20 & NS & 0 & 10 & NS \\
\hline \multirow[t]{5}{*}{ IFN- $\gamma$} & Epithelium $\geq 2$ & 0 & 80 & 20 & 0.048 & 30 & 0 & NS \\
\hline & Matrix & 75 & 100 & 40 & NS & 80 & 40 & NS \\
\hline & Lymphocyte & 75 & 60 & 40 & NS & 30 & 50 & NS \\
\hline & Fibrocyte & 75 & 100 & 50 & NS & 30 & 100 & 0.003 \\
\hline & Neutrophil & 0 & 0 & 40 & NS & 20 & 0 & NS \\
\hline \multirow[t]{4}{*}{ IL-I0* } & Matrix & 100 & 20 & 70 & 0.048 & 80 & 40 & NS \\
\hline & Lymphocyte & 100 & 20 & 70 & 0.048 & 40 & 50 & NS \\
\hline & Fibrocyte & 100 & 60 & 70 & NS & 20 & 100 & NS \\
\hline & Neutrophil & 50 & 0 & 10 & NS & 0 & 10 & NS \\
\hline
\end{tabular}

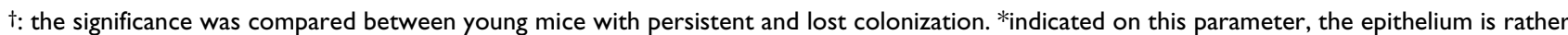
weak for such cytokine on immunohistochemistry staining. 
Table 4: A low gastric IFN- $\gamma($ score $\leq I)$ expression on the epithelium coexisting with high sialyl-Le ${ }^{x}$ (score $\geq 7$ ) and IL- 10 (on both matrix and lymphocytes) was correlated to persistent bacterial colonization in the early acquisition age of mice.

\begin{tabular}{|c|c|c|c|c|}
\hline \multirow[t]{2}{*}{ Cytokine expression (\%) } & \multicolumn{2}{|c|}{ Colonization of young mice } & \multirow[t]{2}{*}{ OR $(95 \% \mathrm{Cl})$} & \multirow[t]{2}{*}{$P$ value* } \\
\hline & Persistent $(n=4)$ & Lost $(n=5)$ & & \\
\hline Low IFN- $\gamma$ & 100 & 20 & $0.2(0.1-1.2)$ & 0.048 \\
\hline High IL- 10 & 100 & 0 & - & 0.008 \\
\hline Low IFN- $\gamma$ and high sialyl-Lex & 100 & 0 & - & 0.008 \\
\hline Low IFN- $\gamma$ and high IL-I0 & 100 & 0 & - & 0.008 \\
\hline
\end{tabular}

OR: odd ratio; $\mathrm{Cl}$ : confidence interval; *: Fisher's exact test

mice is also compatible to support the fact that late acquisition of $H$. pylori in adult human patients usually results in chronic colonization [20]. Moreover, as compared to the $2^{\text {nd }}$ week of young mice after $H$. pylori acquisition, the colonization rate in the $8^{\text {th }}$ week was $53 \%$, which supports that spontaneous elimination of $H$. pylori really occurs during the early acquisition age of mice. So the present study should be highly original to introduce a mouse model designed to validate that there should be a loss of $H$. pylori colonization after an earlier acquisition of $H$. pylori, which closely mimics the clinical findings in young children.

Our previous study has shown that the intensity of gastric $\mathrm{Le}^{\mathrm{x}}$ is positively related to the increment of age in humans [12]. However, for those without $H$. pylori infection, the expression of sialyl-Le ${ }^{\mathrm{x}}$ on gastric epithelium is weak or lacking in dyspeptic children and adults [12]. Compatible with humans, the intensity of gastric sialyl-Le ${ }^{\mathrm{x}}$ of mice is also positively correlated to the increment of age (Figure 2B). Such a finding in mice is also compatible to a rat study, which disclosed an age-related increment of glycosylation in liver tissues [21]. Increasing gastric sialyl-Lex expression after $H$. pylori infection has been reported in humans and Rhesus monkeys [9-12]. However, in our mice study, a decreased intensity of gastric sialyl-Le ${ }^{\mathrm{x}}$ was disclosed in the $H$. pylori-infected young mice, but not in adult mice on the $2^{\text {nd }}$ week, as compared to the control mice. More strikingly, on the $8^{\text {th }}$ week after $H$. pylori acquisition, such a decrease of sialyl-Le $e^{\mathrm{x}}$ disappeared in both the colonized young and adult mice, which had a fully sialylated gastric mucosa. This finding suggests that $H$. pylori challenge should be involved to disturb the age-related maturation curve of sialylation in the young mice. Moreover, it indirectly suggests that the changes of sialyl-Lewis antigen in young mice should be highly correlated to the persistence or loss of $H$. pylori colonization.

In this animal model, early $H$. pylori acquisition caused a higher CIS than in controls on the $2^{\text {nd }}$ week $(87.5 \%$ vs. $50 \%, P=0.15)$, but not on the $8^{\text {th }}$ week $(40 \%$ vs. $30 \%, P$ $=0.36)$ after $H$. pylori challenge. Assuming that dense inflammation causes more severe clinical symptoms, this histology change could be correlated to our previous findings that $H$. pylori infection could cause short-term epigastric pain in children, although usually resolved at followup [22]. Concerning both clinical observation and in vivo mice model data, $H$. pylori acquisition in children usually presents as a self-limited sequel in inflammation.

After H. pylori infection, the different host responses of the gastric cytokines could possibly be related to different

Table 5: The score of IFN- $\gamma$ on the epithelium and IL- 10 on the matrix and lymphocytes at the $8^{\text {th }}$ week after $H$. pylori challenge in the young mice with and without persistent colonization.

\begin{tabular}{|c|c|c|c|c|}
\hline \multirow[b]{2}{*}{ Mice No. } & \multirow[b]{2}{*}{ Colonization } & \multirow[b]{2}{*}{ Score of IFN- $\gamma$ on epithelium } & \multicolumn{2}{|c|}{ Score of IL- I0 } \\
\hline & & & on matrix & on lymphocyte \\
\hline I & Yes & 0 & I & I \\
\hline 2 & Yes & 0 & I & 1 \\
\hline 3 & Yes & 0 & I & I \\
\hline 4 & Yes & 0 & I & 1 \\
\hline 5 & No & I & 0 & 0 \\
\hline 6 & No & 2 & I & 0 \\
\hline 7 & No & 2 & 0 & 0 \\
\hline 8 & No & 2 & 0 & 0 \\
\hline 9 & No & 2 & 0 & I \\
\hline
\end{tabular}


clinical outcomes $[14,18,23,24]$. In this study, the naïve mice were found to have regular IL- $1 \beta$ and IFN- $\gamma$ expressions (Figure 3C \&3D) on the gastric epithelium, which is consistent with a previous report in humans [15]. Our mice study exhibited an age-specific cytokine expression on the gastric epithelium (IFN- $\gamma$ ) and lamina propria (IL6 , TNF- $\alpha$, IFN- $\gamma$, and IL-10). Due to the age-specific response of the cytokines, our study supports that there should be different naïve immune responses between children and adults.

Based on the immunohistochemical study, this study confirmed that the pro-inflammatory cytokine expressions on the gastric lamina propria could change on both the $2^{\text {nd }}$ and the $8^{\text {th }}$ week after $H$. pylori challenge $[25,26]$. Both in mice and in humans, the gastric cytokine responses of $H$. pylori infection have been demonstrated to be Th1-dominant, because the level of IFN- $\gamma$ is increased in $H$. pyloriinfected subjects compared to controls $[15,18,23,27]$. A high INF- $\gamma$ level has been attributed as hallmark of $H$. pylori-related gastritis, especially during chronic inflammation and potentially attributed as a protective role against $H$. pylori colonization $[16-18,28]$. As shown in Table 3, we disclosed that young mice with a loss of colonization had a higher IFN- $\gamma$ expression on the epithelium than the mice with persistent colonization $(P=0.048)$. This finding is compatible with a human study in children which showed that children with $H$. pylori infection had a lower concentration of IFN- $\gamma$ than in non-infected controls [29]. This data in mice suggests that there may be a significant correlation to colonization loss once there is a high expression of IFN- $\gamma$. Therefore, it should be concerned to survey the different host response of IFN- $\gamma$ that can be related to have different $H$. pylori infection outcomes in children.

IL-10 is a Th2 cytokine, and can be triggered by compensatory regulation after a Th1 shift by the H. pylori challenge to protect the gastric mucosa $[13,15,23,27]$. Therefore, it is not so striking to illustrate a significant increase of IL-10 expression in the young mice with persistent colonization (Table 3 ). As shown in Table 4, the young mice with low IFN- $\gamma$ on the epithelium to have a persistence of $H$. pylori colonization had a $100 \%$ coexistence with a high IL-10 expression on the matrix and lymphocytes. These data once again support that upregulation of IL-10 in such mice should be a co-existed compensatory regulation after a drop in IFN- $\gamma$ to serve as a protective role for the infected mucosa. In addition to coexistence with high IL-10, the persistently $H$. pylori-colonized young mice exclusively had low IFN- $\gamma$ and high sialyl-Lex coexpressions on the epithelium compared to those without colonization. These data once again suggest that the host response having a low IFN- $\gamma$ should somewhat coexist with a high sialylation of Lewis antigen, which can possibly serve as putative receptors for $H$. pylori colonization.

\section{Conclusion}

In conclusion, this animal model with early acquisition of $H$. pylori represents a similar course of $H$. pylori infection to that in early childhood. A high expression of sialyl-Lex and a depletion of IFN- $\gamma$ on the gastric epithelium coexisting with high IL-10 in infected young mice should be related to maintaining the persistent colonization of $H$. pylori. Targeting the sialylation or enhancing the IFN- $\gamma$ expression on the gastric epithelium should be promising to decrease the persistent colonization of $H$. pylori in childhood or even in adulthood.

\section{Competing interests}

The authors guarantee that there is no financial relationship with any company. There are no competing interests including the study design, the collection, analysis, and interpretation of data, the writing of the report, and the decision to submit the paper for publication.

\section{Authors' contributions}

YYJ contributed to the study design, study performance, and wrote the first draft of the manuscript. YHB, an experienced pathologist, read the histology and Lewis staining of each biopsy. WJJ also contributed to the study design, technique consultation, and paper revision. SBS, the correspondence author, organized the whole study design, team discussion, and final revision of this paper.

\section{Acknowledgements}

The study was supported by grants NSC93-23।4-B-006-064 and NSC9623 I4-B-006-009 from the National Science Council, Taiwan, ROC.

\section{References}

I. Marshall BJ, Warren JR: Unidentified curved bacilli in the stomach of patients with gastritis and peptic ulceration. Lancet 1984, I:|3||-13|5.

2. Macarthur C, Saunders N, Feldman W: Helicobacter pylori, gastroduodenal disease, and recurrent abdominal pain in children. I Am Med Assoc 1995, 273:729-734.

3. Granstrom M, Tindberg Y, Blennow M: Seroepidemiology of Helicobacter pylori infection in a cohort of children monitored from 6 months to II years of age. J Clin Microbiol 1997, 35:468-470.

4. Malaty HM, El-Kasabany A, Graham DY, Miller CC, Reddy SG, Srinivasan SR, Yamaoka Y, Berenson GS: Age at acquisition of Helicobacter pylori infection: a follow-up study from infancy to adulthood. Lancet 2002, 359:931-935.

5. Ashorn M, Maki M, Hallstrom M, Uhari M, Akerblom HK, Viikari J, Miettinen $A$ : Helicobacter pylori infection in Finnish children and adolescents: A serologic cross-sectional and follow-up study. Scand J Gastroenterol 1995, 30:876-879.

6. Klein PD, Gilman RH, Leon-Barua R, Diaz F, Smith EO, Graham DY: The epidemiology of Helicobacter pylori in Peruvian children between 6 and 30 months of age. Am J Gastroenterol 1994, 89:2196-2200.

7. Ilver D, Arnqvist A, Ogren J, Frick IM, Kersulyte D, Incecik ET: Helicobacter pylori adhesin binding fucosylated histo-blood group antigens revealed by retagging. Science 1998, 279:373-377.

8. Gerhard M, Lehn N, Neumayer N, Boren T, Rad R, Schepp W: Clinical relevance of the Helicobacter pylori gene for blood-group 
antigen-binding adhesin. Proc Natl Acad Sci USA 1999, 96: $12778-12783$.

9. Sheu BS, Sheu SM, Yang HB, Huang AH, Wu J]: Host gastric Lewis expression determines the bacterial density of Helicobacter pylori in babA2 genopositive infection. Gut 2003, 52:927-932.

10. Mahdavi J, Sonden B, Hurtig M, Olfat FO, Forsberg L, Roche N: Helicobacter pylori SabA adhesin in persistent infection and chronic inflammation. Science 2002, 297:573-578.

II. Sheu BS, Odenbreit S, Hung KH, Liu CP, Sheu SM, Yang HB, Wu J]: Interaction between host gastric sialyl-Lewis $x$ and $H$. pylori SabA enhances $H$. pylori density in patients lacking gastric Lewis b antigen. Am J Gastroenterol 2006, I0 I:36-44.

12. Yang YJ, Wu Jj, Sheu BS, Chen CR, Lu CC, Yang HB: Helicobacter pylori infection can change the intensity of gastric Lewis antigen expressions differently between adults and children. J Biomed Sci 2008, 15:29-36.

13. Yamaoka Y, Kita M, Kodama T, Imamura S, Ohno T, Sawai N, Ishimaru A, Imanishi J, Graham DY: Helicobacter pylori infection in mice: role of outer membrane proteins in colonization and inflammation. Gastroenterology 2002, I 23:1992-2004.

14. Kamradt AE, Greiner M, Ghiara P, Kaufmann SHE: Helicobacter pylori infection in wild-type and cytokine-deficient C57BL/6 and BALB/c mouse mutants. Microbes Infect 2000, 2:593-597.

15. Lindholm C, Quiding-Jarbrink M, Lonroth H, Hamlet A, Svennerholm AM: Local cytokine response in Helicobacter pylori-infected subjects. Infect Immun 1998, 66:5964-597I.

16. D'Elios MM, Manghetti M, De Carli M, Costa F, Baldari CT, Burroni $D$, Telford JL, Romagnani S, Del Prete G: T helper I effector cells specific for Helicobacter pylori in the gastric antrum of patients with peptic ulcer disease. J Immunol I997, 158:962-967.

17. Bamford KB, Fan X, Crowe SE, Leary JF, Gourley WK, Luthra GK, Brooks EG, Graham DY, Reyes VE, Ernst PB: Lymphocytes in the human gastric mucosa during Helicobacter pylori have $T$ helper cell I phenotype. Gastroenterology 1998, I | 4:482-492.

18. Sawai N, Kita M, Kodama T, Tanahashi T, Yamaoka Y, Tagawa Y, Iwakura $Y$, Imanishi J: Role of gamma interferon in Helicobacter pylor i-induced gastric inflammatory responses in a mouse model. Infect Immun 1999, 67(I):279-285.

19. Sheu BS, Yang HB, Wu JJ, Huang AH, Lin XZ, Su IJ: Development of Helicobacter pylori infection model in BALB/c mice with domestic cagA-positive and -negative strains in Taiwan. Dig Dis Sci 1999, 44:868-875.

20. Xia HH, Talley NJ: Natural acquisition and spontaneous elimination of Helicobacter pylori infection: clinical implications. Am J Gastroenterol 1997, 92: 1780- I 787.

21. Lityska A, Przybylo M: Does glycosylation of lysosomal proteins show age-related changes in rat liver? Mech Ageing Dev 1998, 102:33-43.

22. Yang YJ, Sheu BS, Lee SC, Wu Jj: Short-term recurrent abdominal pain related to Helicobacter pylori infection in children. J Gastroenterol Hepatol 2005, 20:395-400.

23. Itoh T, Seno H, Kita T, Chiba T, Wakatsuki Y: Th response to Helicobacter pylori differs between patients with gastric ulcer and duodenal ulcer. Scan J Gastroenterol 2005, 40:64I-647.

24. Bontems P, Robert F, Gossum AV, Cadranel S, Mascart F: Helicobacter pylori modulation of gastric and duodenal mucosal $T$ cell cytokine secretions in children compared with adults. Helicobacter 2003, 8:216-226.

25. Yamaoka Y, Kita M, Kodama T, Sawai N, Imanishi J: Helicobacter pylori cagA gene and expression of cytokine messenger RNA in gastric mucosa. Gastroenterology 1996, I I 0: 1744-1752.

26. Yamaoka $Y$, Yamauchi $K$, Ota $H$, Sugiyama A, Ishizone S, Graham DY, Maruta F, Murakami M, Katsuyama T: Natural history of gastric mucosal cytokine expression in Helicobacter pylori gastritis in Mongolian gerbils. Infect Immun 2005, 73:2205-22I 2 .

27. Karttunen R, Karttunen T, Ekre HE, MacDonald TT: Interferon gamma and interleukin 4 secreting cells in the gastric antrum in Helicobacter pylori positive and negative gastritis. Gut 1995, 36:34|-345.

28. Akhiani AA, Pappo J, Kabok Z, Schon K, Gao W, Franzen LE, Lycke $\mathrm{N}$ : Protection against Helicobacter pylori infection following immunization is IL- I 2-dependent and mediated by Th I cells. J Immunol 2002, 169:6977-6984.

29. Maciorkowska E, Panasiuk A, Kaczmarsk M: Concentrations of gastric mucosal cytokines in children with food allergy and
Helicobacter pylori infection. World I Gastroenterol 2005, I I:675I-6756.
Publish with Biomed Central and every scientist can read your work free of charge

"BioMed Central will be the most significant development for disseminating the results of biomedical research in our lifetime. "

Sir Paul Nurse, Cancer Research UK

Your research papers will be:

- available free of charge to the entire biomedical community

- peer reviewed and published immediately upon acceptance

- cited in PubMed and archived on PubMed Central

- yours - you keep the copyright

Submit your manuscript here:

http://www.biomedcentral.com/info/publishing_adv.asp 